\title{
The role of riverine forests for food supply for the omnivorous fish Brycon opalinus Cuvier, 1819 (Characidae) in the Serra do Mar, Southeast Brazil
}

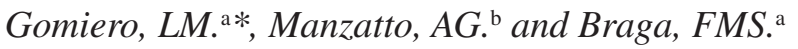 \\ a Departamento de Zoologia, Instituto de Biociências, Universidade Estadual Paulista - UNESP, \\ Av. 24-A 1515, CEP 13506-900, CP 199, Rio Claro, SP, Brasil \\ 'Laboratório de Biogeoquímica Ambiental, Núcleo de Ciência e Tecnologia, \\ Campus José Ribeiro Filho, Universidade Federal de Rondônia - UNIR, \\ BR 364, Km 9,5, CEP 78900-500, Porto Velho, Rondônia, Brasil \\ *e-mail: leanmg@rc.unesp.br
}

Received September 15, 2006 - Accepted February 2, 2007 - Distributed May 31, 2008

(With 6 figures)

\begin{abstract}
The purpose of this study was to characterize the diet of the fish Brycon opalinus (Characidae) seasonally and locally, allowing for the determination of its food items and trophic relations with the aquatic and terrestrial environments. The study area encompasses three rivers (Paraibuna, Ipiranga and Grande) in the basin of the Paraibuna, southeast Brazil. Twelve monthly collections were made from January to December 2004. The degree of stomachic repletion and of accumulated visceral fat was analyzed, as was the intestinal length in each class of total length. The frequency of occurrence and the degree of food preference (DFP) of the food items of Brycon opalinus were determined by separating the vegetal and animal items, autochthonous and allochthonous, by insect order and vegetal family consumed. The frequency of occurrence of items of animal origin was found to be equivalent to that of vegetal origin, thus characterizing the omnivorism of Brycon opalinus feeding.
\end{abstract}

Keywords: Atlantic rainforest, Brycon opalinus, frugivores, omnivorism, seed dispersal.

\section{O papel das florestas ribeirinhas na alimentação do peixe onívoro Brycon opalinus (Characidae) na Serra do Mar, sudeste do Brasil}

\begin{abstract}
Resumo
O objetivo foi caracterizar a dieta do peixe Brycon opalinus (Characidae) sazonalmente e localmente, sendo possível determinar os itens alimentares e as relações tróficas com os ambientes aquáticos e terrestres. A área de estudo abrange três rios (Paraibuna, Ipiranga e Grande) da bacia do Paraibuna, Sudeste do Brasil. Foram realizadas doze coletas mensais de janeiro a dezembro de 2004. O grau de repleção estomacal e o grau de acúmulo de gordura visceral foram analisados, assim como o comprimento intestinal em cada classe de comprimento total. A frequiência de ocorrência e o grau de preferência alimentar (GPA) dos itens alimentares de Brycon opalinus foram obtidos separando-se os itens vegetais e animais, autóctones e alóctones, por ordem de insetos e por família de vegetais consumidos. A frequiência de ocorrência dos itens de origem animal equivale à dos de origem vegetal, caracterizando assim a onivoria na alimentação de Brycon opalinus.
\end{abstract}

Palavras-chave: Mata Atlântica, Brycon opalinus, frugívoros, onivoria, dispersão de sementes.

\section{Introduction}

The riparian zone occurs at the interface between aquatic and terrestrial ecosystems and regulates the transfer of energy between these systems, as well as insolation in the aquatic system (Pusey and Arthington, 2003). These sites shelter a wide diversity and density of invertebrates when compared to the adjacent forests and comprise some of the earth's most productive ecosystems. In oligotrophic streams, the terrestrial matter carried into the water supplies an important food resource for fishes; hence, the riparian integrity is extremely important for the survival of these species (Pusey and Arthington, 2003; Melo et al., 2004). In addition to being highly sensitive to environmental changes, the riparian zone is a key factor in the maintenance of the basin's resilience (Lima, 2003).

The Atlantic Forest of Brazil has undergone intensive deforestation and its conservation status is defined as critical (Myers et al., 2000; Araújo-Lima et al., 2004). Anthropic activities have put freshwater fishes, from the smallest streams to the largest rivers, under profound and 
usually negative pressure. Despite its enormous importance as the principal river basin situated between the country's two greatest urban and industrial centers, São Paulo and Rio de Janeiro, the Paraíba do Sul river has received little attention from the standpoint of ecosystem studies and little has been reported about this environment. This basin covers approximately 57,000 square kilometers on the bottom of the valley between the Mar and Mantiqueira mountain ranges (Araújo, 1998). In each geographical area, some species are the first to disappear as anthropic pressures increase, and among fish, this is particularly true of the genus Brycon (Araújo, 1998). This disappearance can be attributed to the degradation of water quality, of the habitat, or a combination of the two, e.g., high loads of suspended matter and the resulting silting (Araújo op. cit.), as well as the construction of hydroelectric power plants and the loss of riverine forests.

The genus Brycon comprises at least 67 species distributed geographically from Mexico to the La Plata river basin, and also occurs in the coastal rivers of the Pacific, Colombia, Ecuador and northern Peru (Lima and Castro, 2000). The Pirapitinga do Sul (Brycon opalinus Cuvier, 1819) occurs in the headwaters of the Paraíba do Sul basin. It is endemic to this area and, today, is under threat of extinction (Hilsdorf and Petrere Jr., 2002). Fruit- and seed-eating fishes are concentrated in a few phylogenetic groups, and many of them belong to the families Characidae and Anostomidae (Characiformes), and Pimelodidae and Doradidae (Siluriformes), for whom the trees of riparian forests are an important food resource in tropical streams, because of both the availability of fruit and seeds and of insects (Araújo-Lima et al., 2004).

The wide trophic adaptability of teleosts is reflected in the predominance of generalist and opportunist species, particularly in the tropical fluvial environments, where food diversity is high. The occurrence of a flexible diet is a marked characteristic of the tropical fluvial ichthyofauna, most of whose species are able to change from one food to another in response to oscillations in the relative abundance of the food resource in use resulting from spatial and temporal alterations of the environment (Abelha et al., 2001). The fishes that inhabit the headwaters of streams depend primarily on allochthonous foods (terrestrial insects and vegetals), and are euritrophic, with little food specialization (Lowe-McConnell, 1999), and in most cases opportunists (Braga, 1990).

The considerable trophic plasticity of opportunistic species can be seen as an expression of the ability to use a diversity of food resources under adverse conditions, in which less tolerant species would be unable to use these resources (Teixeira et al., 2005). The balance of input of the allochthonous matter in trophic chains can influence the stability of ecosystems, and serious environmental consequences may occur if this balance is altered by anthropic actions (Jefferies, 2000).
Knowledge of the interactions between fish and riparian systems is essential for the rehabilitation of degraded environments and for the prevention of the deterioration of freshwater fish populations (Pusey and Arthington, 2003). Little information is available when one considers the importance of allochthonous food sources for the ichthyofauna of streams, which, in many regions, is being destroyed even before a better knowledge of the dynamics of this interaction can be acquired (Esteves and Aranha, 1999).

The purpose of this work was to characterize the diet of Brycon opalinus, seasonally and locally, determining its food items and trophic relations with aquatic and terrestrial environments.

\section{Material and Methods}

A total of 12 samples were made monthly from January to December 2004. Each collection period lasted four days. Three sites in the Paraibuna basin were selected for the collections: the Paraibuna, Ipiranga, and Grande rivers. These sites are located within of the Santa Virginia Nucleus of the Serra do Mar State Park $\left(23^{\circ} 24^{\prime}-23^{\circ} 17^{\prime} \mathrm{S}\right.$ and $\left.45^{\circ} 03^{\prime} \mathrm{W}\right)$. At each sample point, individuals were collected using gill nets with mesh sizes of $1.5 ; 2.0 ; 2.5 ; 3.0 ; 3.5$, and $4.0 \mathrm{~cm}$, measured between adjacent knots (10 m long and $1.5 \mathrm{~m}$ high), and totalizing $60 \mathrm{~m}$. In addition to the nets, sieves, and traps were also used. Fishing effort was standardized, keeping time and the quantity of instruments employed at each point constant.

Total length of individuals were measured in centimeters, mass was measured in grams, repletion degree of the stomach, fat degree in the visceral cavity and intestine length in centimeters. Three categories, according to a previously established scale, indicated the repletion and fat degrees: 1 . empty; 2. partially full; and 3. replete (Braga, 1990). The frequencies of the repletion degree of the stomach and of the fat degree in the visceral cavity were used to characterize the feeding of Brycon opalinus per period collection. The stomachs were withdrawn from the visceral cavity, weighed, and kept in alcohol diluted at 70\% (Zavala-Camin, 1996). Food items were identified with stereomicroscopic up to the lowest taxonomic level reached.

The method of Frequency of Occurrence (Hyslop, 1980) was also used, which is the percentage between the number of stomachs with items from a determined taxonomic group and the total number of stomachs with food. The frequency of occurrence of the food items of Brycon opalinus was determined by separating the vegetal and animal items, both autochthonous and allochthonous, by insect order and the vegetal family it consumes.

The IQ (intestinal quotient) is the result of the division between the length of the intestine and the length of the fish, and is used to relate the intestine's relative length to the diet (Zavala-Camin, 1996). The IQ was esti- 
mated by the collection point, between the sexes and the classes of total length.

To analyze the alimentary items found in stomachs with degree 3 (replete) of the repletion, the degree of food preference (DFP), was used following Braga (1999) in accordance with the formula: $\mathrm{DFP}=\mathrm{Si} / \mathrm{N}$, where $\mathrm{Si}$ is the sum of the values related to abundance of the food item (i) in the stomachs and N, the total number of the stomachs analyzed. The estimated value for the Degree of Food Preference (DFP) for each item is indicated by:

- $\mathrm{DFP}=4$ : the chosen item has absolute preference;

- $3<\mathrm{DFP}<4$ : the chosen item has high preference degree;

- $2<$ DFP $<3$ : the chosen item is preferential, otherwise different items are ingested;

- $1<\mathrm{DFP}<2$ : the chosen item is secondary; and

- $0<\mathrm{DFP}<1$ : the chosen item is occasional.

Comparisons of diets obtained by the DFP method between animal and vegetal origins were made by the Mann-Whitney U-test, a non-parametric technique for comparing the medians of two unmatched samples (Siegel, 1975).

\section{Results}

The frequency of occurrence of the food items was determined based on an analysis of the 256 stomachic and intestinal contents of Brycon opalinus. The degree of stomachic repletion 3 (replete) and of accumulated fat in the visceral cavity 3 occurred in greater number in the specimens collected in the spring, summer and early autumn (Figure 1).

The mean IQ for all the individuals of Brycon opalinus was 0.86 . The average IQ values were similar in the various collection sites, but the intestinal quotients of immature individuals and of individuals with a total length of 12 to $16 \mathrm{~cm}$ were relatively lower than the oth- ers. From an overall standpoint, the IQ values evidenced omnivorism, with the smaller classes of total length showing a tendency to ingest a larger quantity of items of animal origin (Table 1).

Allochthonous insects were more frequent than autochthonous insects. The frequency of occurrence of food items of animal origin was equivalent to that of items of vegetal origin, thus characterizing omnivorism in the feeding habits of Brycon opalinus (Figure 2).

Of the 14 insect orders found, the most important ones were Coleoptera and Hymenoptera. Several families and species of orders of insects consumed by Brycon opalinus were identified, the most diverse order being Coleotera, which presented 9 families (Table 2). The stomachic and intestinal contents contained 25 plant

Table 1. Intestinal quotient (IQ) of Brycon opalinus in rivers of the Serra do Mar, southeast Brazil.

\begin{tabular}{lrcc}
\hline \multicolumn{1}{c}{ Sites } & N & IQ $($ Mean \pm SD $)$ & Interval \\
\hline Paraibuna & 95 & $0.86 \pm 0.12$ & $(1.3-0.51)$ \\
Ipiranga & 97 & $0.87 \pm 0.14$ & $(1.24-0.49)$ \\
Grande & 31 & $0.83 \pm 0.9$ & $(1.03-0.58)$ \\
Total & 223 & $0.86 \pm 0.13$ & $(1.3-0.49)$ \\
\hline \multicolumn{1}{c}{ Sex } & $\mathbf{N}$ & IQ (Mean \pm SD) & Interval \\
\hline Males & 59 & $0.87 \pm 0.14$ & $(1.3-0.51)$ \\
Females & 151 & $0.86 \pm 0.12$ & $(1.24-0.58)$ \\
Immatures & 13 & $0.77 \pm 0.12$ & $(0.95-0.49)$ \\
\hline Length $(\mathbf{c m})$ & $\mathbf{N}$ & IQ $($ Mean $\pm \mathbf{S D})$ & Interval \\
\hline $12 \mid-16$ & 4 & $0.79 \pm 0.07$ & $(0.7-0.88)$ \\
$16 \mid-20$ & 38 & $0.87 \pm 0.14$ & $(1.12-0.54)$ \\
$20 \mid-24$ & 53 & $0.89 \pm 0.14$ & $(1.3-0.49)$ \\
$24 \mid-28$ & 52 & $0.84 \pm 0.13$ & $(1.2-0.51)$ \\
$28 \mid-32$ & 52 & $0.85 \pm 0.12$ & $(1.24-0.59)$ \\
$32 \mid-36$ & 24 & $0.81 \pm 0.09$ & $(0.95-0.59)$ \\
\hline
\end{tabular}

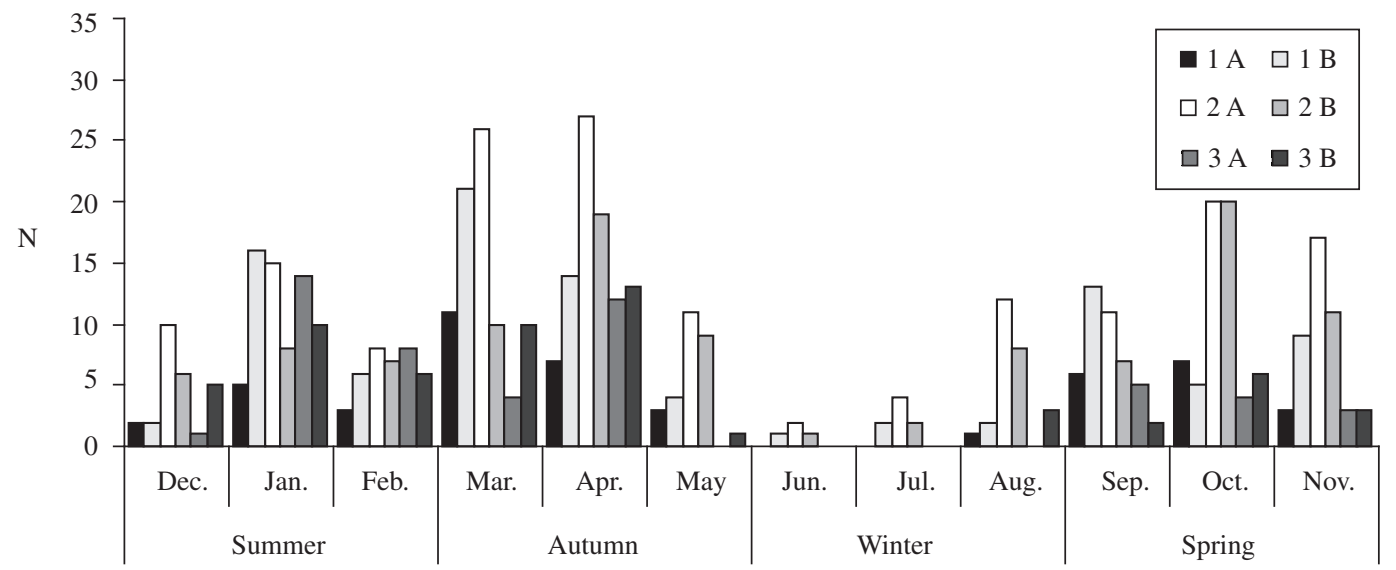

Samples

Figure 1. a) numerical distribution of individuals of Brycon opalinus according to the degrees of stomach repletion; and b) accumulated fat being: 1: empty, 2: partially full, and 3: replete in each collection period. 
families of 51 species, the most frequent families were Euphorbiaceae, Myrtaceae and Melastomataceae (Figure 3).

To identify the DFP (Degree of Food Preference), an analysis was made of 54 stomach contents with a repletion degree of 3 . This analysis revealed that the items (allochthonous insects; fruits and seeds) with the highest values (1.5) were secondary. All the other food items were occasional, evidencing the opportunism and wide diversity of food items consumed by this species (Figure 4). In terms of insects, the DFP showed that all the items were occasional, with Coleoptera and Hymenoptera being the most important items (Figure 5). As for the fruit and seed families consumed, the DFP indicated these food items were also occasional, with Euphorbiaceae and Myrtaceae showing the highest values (Figure 6).

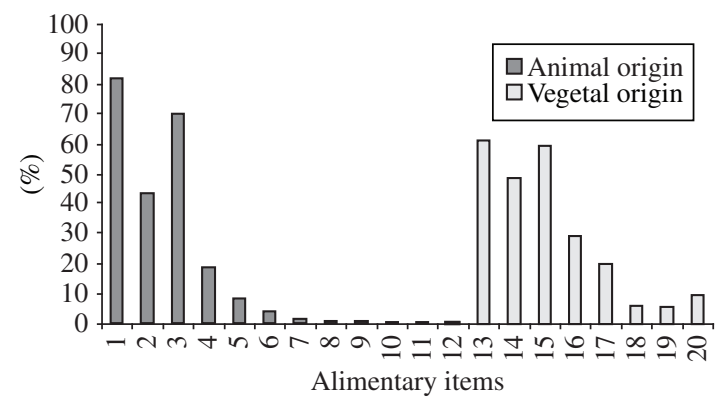

Figure 2. Frequency of occurrence of food items for the species Brycon opalinus, with the items of animal origin being: 1: Allochthonous insects, 2: Autochthonous insects, 3: Rests of Insects, 4: Nematodes, 5: Crustaceans, 6: Arachnids, 7: Diplopoda, 8: Mollusca, 9: Amphibians, 10: Feathers, 11: Mammals, 12: Platyhelminths; and items of vegetal origin being: 13: Fruits and seeds, 14: Rests of fruits and seeds, 15: Vegetal Matter, 16: Flower Buds, 17: Algae, 18: Bryophytes, 19: Macrophytes, and 20: Sediments.

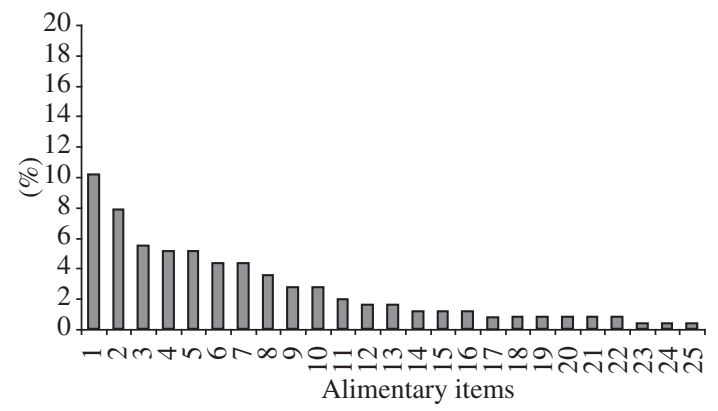

Figure 3. Frequency of occurrence of the families of fruits and seeds in the digestive tract of Brycon opalinus, these items being: 1: Euphorbiaceae, 2: Myrtaceae, 3: Melastomataceae, 4: Rubiaceae, 5: Solanaceae, 6: Viscaceae, 7: Aquifoliaceae, 8: Moraceae, 9: Graminae, 10: Bombacaceae, 11: Annonaceae, 12: Lauraceae, 13: Fabaceae, 14: Onagraceae, 15: Sapotaceae, 16: Nyctaginaceae, 17: Violaceae, 18: Cecropiaceae, 19: Asteraceae, 20: Sapindaceae, 21: Boraginaceae, 22: Araliaceae, 23: Rutaceae, 24: Rosaceae, and 25: Meliaceae.

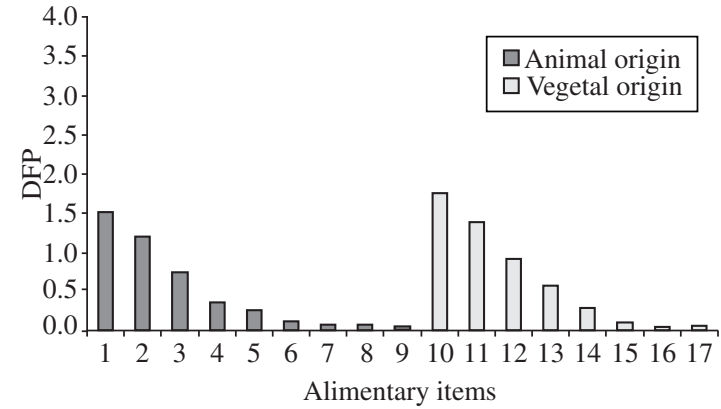

Figure 4. Degree of food preference (DFP) of the food items for the species Brycon opalinus, with the items of animal origin being: 1: Allochthonous insects, 2: Rests of Insects, 3: Autochthonous insects, 4: Nematodes, 5: Crustaceans, 6: Amphibians, 7: Diplopoda, 8: Mammal, 9: Arachnids; and items of vegetal origin being: 10: Fruits and seeds, 11: Rests of fruits and seeds, 12: Vegetal Matter, 13: Flower Buds, 14: Algae, 15: Macrophytes, 16: Bryophytes, and 17: Sediments.

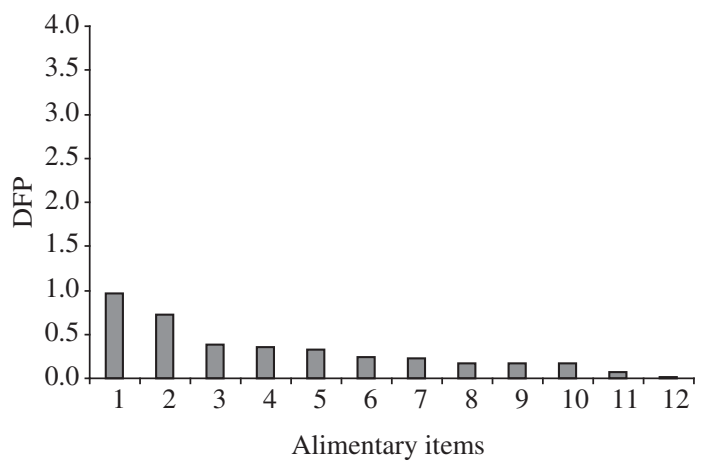

Figure 5. Degree of food preference (DFP) of the orders of insects in the digestive tract of Brycon opalinus, i.e.,: 1: Coleoptera, 2: Hymenoptera, 3: Diptera, 4: Blattaria, 5: Trycoptera, 6: Isoptera, 7: Hemiptera, 8: Lepidoptera, 9: Odonata, 10: Orthoptera, 11: Neuroptera, and 12: Ephemeroptera.

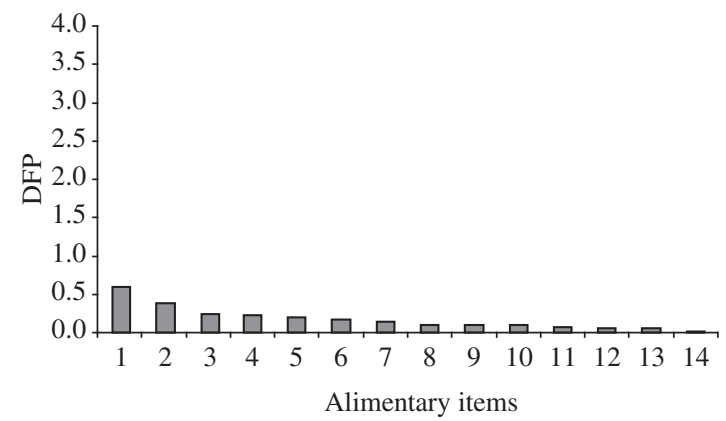

Figure 6. Degree of food preference (DFP) of the families of fruits and seeds in the digestive tract of Brycon opalinus, these items being: 1: Euphorbiaceae, 2: Myrtaceae, 3: Solanaceae, 4: Aquifoliaceae, 5: Melastomataceae, 6: Rubiaceae, 7: Annonaceae, 8: Moraceae, 9: Fabaceae, 10: Sapotaceae, 11: Viscaceae, 12: Graminae, 13: Lauraceae, and 14: Bombacaceae. 
Table 2. Frequency of occurrence (\%) of the orders of insects in the digestive tract of Brycon opalinus, with respective family, sub-family and species (classification according to Triplehorn and Johnson, 2005).

\begin{tabular}{|c|c|c|c|c|c|}
\hline Ordem & $(\%)$ & Sub-ordem & Family & Sub-family & Species \\
\hline \multirow[t]{9}{*}{ Coleoptera } & 58.6 & - & Curculionidae & - & - \\
\hline & - & - & Coccinellidae & - & - \\
\hline & - & - & Elateridae & - & - \\
\hline & - & - & Chrysomelidae & - & - \\
\hline & - & - & Mordellidae & - & - \\
\hline & - & - & Naucoriidae & - & - \\
\hline & - & - & Scarabeidae & - & - \\
\hline & - & - & Dytiscidae & - & - \\
\hline & - & - & Cerambicidae & - & - \\
\hline \multirow[t]{7}{*}{ Hymenoptera } & 49.6 & - & Sphecidae & - & - \\
\hline & - & - & Vespidae & - & - \\
\hline & - & - & Formicidae & Ponerinae & - \\
\hline & - & - & - & Formicinae & Camponotus sp. \\
\hline & - & - & - & - & Atta sp. \\
\hline & - & - & Apidae & - & Bombus sp. \\
\hline & - & - & - & - & Apis mellifera \\
\hline Trychoptera & 28.1 & - & - & - & - \\
\hline \multirow[t]{2}{*}{ Diptera } & 27.3 & Cyclorrhapha & Muscidae & - & - \\
\hline & - & Nematocera & Chironomidae & - & - \\
\hline \multirow[t]{5}{*}{ Hemiptera } & 17.2 & Auchenorrhyncha & Cicadidae & - & - \\
\hline & - & - & Cicadellidae & - & - \\
\hline & - & Heteroptera & Gerridae & - & - \\
\hline & - & - & Belastomatidae & - & - \\
\hline & - & - & Miridae & - & - \\
\hline Lepidoptera & 16.7 & - & Geometridae & - & - \\
\hline Isoptera & 11.7 & - & Termitidae & - & - \\
\hline \multirow[t]{2}{*}{ Odonata } & 11.7 & Zygoptera & - & - & - \\
\hline & - & Anysoptera & - & - & - \\
\hline Blattaria & 6.25 & - & Blattidae & - & Periplaneta sp. \\
\hline Ephemeroptera & 6.25 & - & - & - & - \\
\hline \multirow[t]{2}{*}{ Orthoptera } & 5.46 & - & Tettigoniidae & - & - \\
\hline & - & - & Acrididae & - & - \\
\hline Dermaptera & 1.56 & - & - & - & - \\
\hline Neuroptera & 1.17 & Megaloptera & Corydalidae & - & - \\
\hline Plecoptera & 0.4 & - & - & - & - \\
\hline
\end{tabular}

The median of DFP value for vegetal items was 0.57 , larger than the median of 0.26 for animal items $\left(\mathrm{U}_{0.05 ; 9}=12<\mathrm{U}=17.5\right)$. There was therefore a preference of alimentary items of vegetal origin in relation to the ingested items of animal origin.

\section{Discussion}

The feeding activity and consequent accumulation of fat in Brycon opalinus occurred through most of the year, except in the coldest months of winter. In contrast, for Brycon cephalus (Günther, 1869) in Amazonia, replete stomachs were found to be frequent during the different seasons of the year and accumulated fat was the norm throughout the year except during reproduction. The greatest availability of animal protein (insects) in the diet of $B$. cephalus was during the dry season, but the highest source of energy in their food came from fruits and seeds during the flooding season and high floods (PizangoPaima et al., 2001). Seasonal changes in food availability can be caused by modifications in habitats, in the life cycles of food organisms, or even by changes caused by the feeding activity of fish (Wootton, 1990).

Information on IQ values can be very useful when comparing specimens of the same species collected from 
different sites or in different seasons, or in relation to the various ages, aiding in the identification of possible variations in feeding behavior among individuals or populations (Zavala-Camin, 1996). The intestinal quotient of Brycon lundii Lütken, 1875 (São Francisco river basin) and of Brycon opalinus was 0.86 (omnivores) and the transversal arrangement of their intestinal folds probably contributes to the retention of food matter for longer periods (Menin and Mimura, 1992a). The esophagus and stomach of Brycon lundii, which captures food items of different types and sizes, show a large number of folds, thus making them highly distensible (Menin and Mimura, 1992b, 1992c).

The IQ of Brycon opalinus individuals with smaller total lengths indicates the ingestion of food items of primarily animal origin, while the larger ones showed an omnivorous diet. Kramer and Bryant (1995) analyzed 21 species of fish from Panama and found that most of the omnivorous fish increased their consumption of vegetal as their size increased. In Costa Rica, the smaller individuals of Brycon guatemalensis Regan, 1908 fed principally on insects while the largest ones consumed a large proportion of allochthonous vegetal matter, principally of leaves (Burcham, 1988). The largest individuals of Brycon guatemalensis have relatively larger intestines than the juveniles, and pepsins and trypsins have been found to reduce the activity while amylases increase them, thus supporting morphological and biochemical specialization for these fish to become first carnivores and subsequently herbivores during their life cycle. This adaptation of the enzymatic secretions according to the type of food (proteins, carbohydrates and fats) occurred in Brycon melanopterus (Cope, 1872) (Reimer, 1982) and also in Brycon orbignyanus (Valenciennes, 1850), which varies the quantity and composition of its digestive proteases and is able to digest vegetal and animal proteins (Garciá-Carreño et al., 2002). In addition, as in the case of Brycon opalinus, Brycon guatemalensis possesses a large gall bladder, suggesting the importance of the digestion of lipids in these species (Drewe et al., 2004).

According to Abelha et al. (2001), different diets in the same species are frequently found according to the stages of development of individuals, as a result of differences in the energy demand and in morphological limitations, implying differentiated diets during their development. The ability of ichthyofauna to use varied food resources limits any attempt to draw generalized conclusions about their food ecology. Ontogenetic, seasonal, spatial and individual changes in diet, allied to an ample repertoire of feeding tactics, provide examples of this flexibility.

The Pirapitinga do Sul (Brycon opalinus) is a generalist, for it feeds on an ample range of items and is also an opportunist feeder, since it feeds on items that are not usual (amphibians, feathers and mammals), according to Gerking (1994). Other Brycon, such as Brycon melanopterus (Reimer, 1982), Brycon cephalus
(Pizango-Paima et al., 2001; Figueiredo-Garutti et al., 2002), Brycon vermelha Lima and Castro, 2000 and Brycon ferox Steindachner, 1877 (Lima and Castro, 2000), Brycon orbignyanus (García-Carreño et al., 2002; Sá and Fracalossi, 2002), Brycon microlepis Perugia, 1897 (Sabino and Sazima, 1999), Brycon falcatus Müller and Troschel, 1844 (Melo et al., 2004), Brycon lundii (Alvim and Peret, 2004) and Brycon sp. (Jatuarana) (Goulding, 1980), have been characterized as feeding on an omnivorous diet in the most diverse environments.

In rivers with extensive vegetal covering (riparian), photosynthesis is hindered by the lack of sunlight, which renders the primary production small. In these environments, the contribution of allochthonous matter for the ichthyofauna is extremely important, both indirectly and directly through food items (insects) (Rezende and Mazzoni, 2005), and also of vegetal items that fall directly into or are carried to the water. Terrestrial invertebrates are commonly considered allochthonous while aquatic invertebrates are considered autochthonous items. However, insects in immature stages - the principal aquatic invertebrates consumed by fish - are also dependent on terrestrial resources and are therefore of mixed origin, and also dependent on riparian forests (Alvim and Peret, 2004). The contribution of allochthonous matter is important in the food of fish in two ways: a) because it increases the quantity of fruits, seeds and terrestrial insects directly ingested by the ichthyofauna, and/or b) it increases the quantity of particulate organic matter (POM), which is an important food resource for invertebrate organisms and detritivorous fish. With this contribution, streams with higher drift rates sustain a greater biomass of fish (Esteves and Aranha, 1999).

Large schools of Brycon guatemalensis were present in forest streams and usually absent from deforested areas which indicates that the removal of fruit trees from the banks of small streams leads to their local elimination or to a considerable decrease in their abundance (Burcham, 1988), as well as to that of Brycon vermelha and of other species of Brycon that depend on the maintenance of riverine forests (Lima and Castro, 2000). According to Horn (1997), the high degree of interdependence between fishes and trees in tropical forests provides a strong argument in favor of the conservation of both biotic elements of the forest in order to maintain an intact functional state.

In the region of the upper Paraná, rapid deforestation has harmed the fish communities of the rivers located in the most heavily populated areas. The Piracanjuba (Brycon orbignyanus), an herbivorous species specialized in fruits of the riverine forest, has practically disappeared from the rivers of the state of São Paulo as a result of their sensitivity to disturbances such as pollution, deforestation and the lack of adequate food for the species (Barrella et al., 2001). The same fate may befall other species of Brycon if the riverine forests in the areas of occurrence of each species are devastated, with 
the consequent deterioration of habitats and lack of food resources.

Acknowledgements - The authors wish to thank FAPESP (proc.03/05696-1) for their financial support, to Cotec (proc.40.673/03) and to IBAMA (aut.055/2003).

\section{References}

ABELHA, MCF., AGOSTINHO, AA. and GOULART, E., 2001. Plasticidade trófica em peixes de água doce. Acta Scientiarum, vol. 23 , no. 2, p. 425-434.

ALVIM, MCC. and PERET, AC., 2004. Food resources sustaining the fish fauna in a section of the upper São Francisco River in Três Marias, MG, Brazil. Braz. J. Biol. $=$ Rev. Bras. Biol., vol. 64, no. 2, p. 195-202.

ARAÚJO, FG., 1998. Adaptação do índice de integridade biótica usando a comunidade de peixes para o rio Paraíba do Sul. Rev. Bras. Biol. $=$ Braz. J. Biol., vol. 58, no. 4, p. 547-558.

ARAÚJO-LIMA, CARM., HIGUCHI, N. and BARRELA, W., 2004. Fishes-forestry interactions in tropical South América. In NORTHCOTE, TG. And HARTMAN, GF. Fishes and forestry. (Eds). Blackwell Science.

BARRELA, W., PETRERE-Jr., M., SMITH, WS. and MONTAG, LFA., 2001. As relações entre as matas ciliares, os rios e os peixes. In RODRIGUES, RR. and LEITÃO-FILHO, HF. (eds). Matas Ciliares. Conservação e recuperação. Edusp. 320 p.

BRAGA, FMS., 1990. Aspectos da reprodução e alimentação de peixes comuns em um trecho do rio Tocantins entre Imperatriz e Estreito, Estados do Maranhão e Tocantins, Brasil. Rev. Bras. Biol. $=$ Braz. J. Biol., vol. 50, no. 3, p. 547-558.

BRAGA, FMS., 1999. O grau de preferência alimentar: um método qualitativo e quantitativo para o estudo do conteúdo estomacal de peixes. Acta Scientiarum, vol. 21, no. 2, p. 291-295.

BURCHAM, J., 1988. Fish communities and environmental characteristics of two lowland streams in Costa Rica. Rev. Biol. Trop., vol. 36, no. 2A, p. 273-285.

DREWE, KE., HORN, MH., DICKSON, KA. and GAWLICKA, A., 2004. Insectivore to frugivore: ontogenetic changes in gut morphology and digestive enzyme activity in the characid fish Brycon guatemalensis from Costa Rican rain forest streams. $J$. Fish Biol., vol. 64, no. 4, p. 890-902.

ESTEVES, KE. and ARANHA, JMR., 1999. Ecologia trófica de peixes de riachos. In CARAMASCHI, EP., MAZZONI, R. and PERES-NETO, PR., Ecologia de peixes de riachos. Série Oecologia Brasiliensis, v. 6. Rio de Janeiro, PPGEUFRJ. 260 p.

FIGUEIREDO-GARUTTI, ML., NAVARRO, I., CAPILLA, E., SOUZA, RHS., MORAES, G., GUTIÉRREZ, J. and VICENTINI-PAULINO, MLM., 2002. Metabolic changes in Brycon cephalus during post-feeding and fasting. Comp. Biochem. Physiol. Part A, vol. 132, no. 2, p. 467-476.

GARCÍA-CARREÑO, FL., ALBUQUERQUE-CAVALCANTI, C., DEL-TORO, MAN., and ZANIBONI-FILHO, E., 2002. Digestive proteinases of Brycon orbignyanus (Characidae, Teleostei): characteristics and effects of protein quality. Сomp. Biochem. Physiol. Part B, vol. 132, no. 2, p. 343-352.
GERKING, SD., 1994. Feeding ecology of fishes. Academic Press. 416 p.

GOULDING, M., 1980. The fishes and forest: explorations in Amazonian Natural History. Berkeley: University of California Press. 280 p.

HILSDORF, AWS. and PETRERE-Jr, M., 2002. Conservação de peixes na bacia do rio Paraíba do Sul. Ciência Hoje, vol. 30, no. 180 , p. $62-65$.

HORN, MH., 1997. Evidence for dispersal of fig seeds by the fruit-eating characid fish Brycon guatemalensis in a Costa Rican tropical rain forest. Oecologia, vol. 109, no. 2, p. 259-264.

HYSLOP, EJ., 1980. Stomach contents analysis. A review of methods and their application. Journal of Fish Biology, vol. 17, no. 4, p. 411-29.

JEFFERIES, RL., 2000. Allochthonous inputs: integrating population changes and food-web dynamics. TREE, vol. 15, no. 1, p. 19-22.

KRAMER, DL. and BRYANT, MJ., 1995. Intestine length in the fishes of a tropical stream: 2. Relationships to diet-the long and short of a convoluted issue. Env. Biol. Fish., vol. 42, no. 2, p. $129-141$.

LIMA, WP., 2003. Relações hidrológicas em Matas Ciliares. In HENRY, R. (Org). Ecótonos nas interfaces dos ecossistemas aquáticos. São Carlos: Ed. Rima. 349 p.

LIMA, FCT. and CASTRO, RMC., 2000. Brycon vermelha, a new species of characid fish from the rio Mucuri, a coastal river of eastern Brazil (Ostariophysi: Characiformes). Ichthyol. Explor. Freshwaters, vol. 11, no. 2, p. 155-162.

LOWE-MCCONNELL, RH., 1999. Estudos ecológicos de comunidades de peixes tropicais. Tradução de Vazzoler, A. E. A. M., Agostinho, A. A. and Cunnighan, P. São Paulo: Ed. da Universidade de São Paulo. Título original: Ecological studies in tropical fish communities. 535 p.

MELO, CE., MACHADO, FA. and PINTO-SILVA, V., 2004. Feeding habits of fish from a stream in the savanna of Central Brazil, Araguaia basin. Neotrop. Ichthyol., vol. 2, no. 1, p. 37-44.

MENIN, E. and MIMURA, O. M., 1992a, Anatomia funcional comparativa do estômago de três peixes Teleostei de hábito alimentar onívoro. Rev. Ceres, vol. 39, no. 223, p. 233-260.

-, 1992b, Anatomia comparativa de esôfago de seis peixes Teleostei de água doce de distintos hábitos alimentares. Rev. Ceres, vol. 40, no. 230, p. 334-369.

-, 1992c, Anatomia funcional comparativa do intestino de dois peixes Teleostei de água doce de hábito alimentar onívoro. Rev. Ceres, vol. 40, no. 231, p. 450-478.

MYERS, N., MITTERMEIER, RA., MITTERMEIER, CG., FONSECA, GAB. and KENT, J., 2000. Biodiversity hotspots for conservation priority. Nature, vol. 403, no. 6772, p. 853-858.

PIZANGO-PAIMA, EG., PEREIRA-FILHO, M. and OLIVEIRA-PEREIRA, MI., 2001. Composição corporal e alimentar do matrinxã, Brycon cephalus, na Amazônia Central. Acta. Amazonica, vol. 31, no. 3, p. 509-520.

PUSEY, BJ. and ARTHINGTON, AH., 2003. Importance of the riparian zone to the conservation and management of freshwater fish: a review. Marine and Freshwater Research, vol. 54, no. 1, p. 1-16. 
REIMER, G., 1982. The influence of diet on the digestive enzymes of the Amazon fish matrinxã, Brycon cf. melanopterus. J. Fish Biol., vol. 21, no. 6, p. 637-642.

REZENDE, CF. and MAZZONI, R., 2005. Seasonal variation in the input of allochthonous matter in an Atlantic Rain Forest stream, Ilha Grande-RJ. Acta Limnol. Bras., vol. 17, no. 2, p. $167-175$.

SÁ, MVC. and FRACALOSSI, DM., 2002. Exigência protéica e relação energia/proteína para alevinos de piracanjuba (Brycon orbignyanus). Rev. Bras. Zootec., vol. 31, no. 1, p. 1-10.

SABINO, J. and SAZIMA, I., 1999. Association between fruiteating fish and foraging monkeys in Western Brazil. Ichthyol. Explor. Freshwaters, vol. 10, no. 4, p. 309-312.
SIEGEL, S., 1975. Estatística não-paramétrica. Para as ciências do comportamento. Rio de Janeiro: McGraw-Hill do Brasil. 350 p.

TEIXEIRA, TP., PINTO, BCT., TERRA, BF., ESTILIANO, EO., GRACIA, D. and ARAÚJO, F. G., 2005, Diversidade das assembléias de peixes nas quatro unidades geográficas do rio Paraíba do Sul. Iheringia Sér. Zool., vol. 95, no. 4, p. 347-357.

TRIPLEHORN and JOHNSON, 2005. Borror and Delong's introduction to the Study of insects. $7^{\text {th }}$ ed. Thomson and Brooks/ Cole Eds. 864 p.

WOOTON, RJ., 1990. Ecology of teleost fishes. London: Chapman and Hall. 404 p.

ZAVALA-CAMIN, LA., 1996. Introdução aos estudos sobre alimentação natural em peixes. Maringá-PR: Eduem/Nupelia. $129 \mathrm{p}$. 